INDONESIA ACCOUNTING JOURNAL

VOLUME 2, NUMBER 1, YEAR 2020

${ }^{1}$ Corresponding author

Kongregasi Suster-Suster Jesus Maria Joseph

Jl. Trimargo Wetan I

Daerah Istimewa Yogyakarta

Indonesia, 55233

E-mail: annaberibe28@gmail.com

${ }^{2}$ Jurusan Akuntansi

Fakultas Ekonomi dan Bisnis

Universitas Sam Ratulangi

Jl. Kampus UNSRAT

Manado, Indonesia, 95115

Article info:

Received 9 January 2020

Accepted 9 January 2020

Available online 9 January 2020

Keywords: PSAK 23; internal control; cash receipts; disbursements JEL Classification: $\mathrm{H}_{51}$, H10, H59 DOI: http://doi.org/10.3240o/iaj. 27077

\title{
Analisis penerapan PSAK 23 tentang pendapatan jasa pasien Jaminan Kesehatan (JKN) menurut Standar Akuntansi Keuangan terhadap tarif Rumah Sakit Gunung Maria Tomohon?
}

\author{
Anna Ina Wae Beribe ${ }^{1}$ \\ Jullie J. Sondakh ${ }^{2}$
}

\begin{abstract}
Internal control is important for company operational, especially for cash receipts and disbursements. The effective internal control of cash receipts and disbursements can prevent and detect the misappropriation of cash. The purpose of this study is to examine the implementation of PSAK 23 at Mountain Marry Hospital regarding the recording, presentation, and recognition of hospital revenue that serves patients with the same actions but acknowledgment of payment of different rates between hospital rates and Indonesian-Case Based Groups (INACBG) rates, specifically for patients of the Implementing Agency Social Security (BPJS) Health. This research was conducted at Mountain Marry Hospital to analyze and to apply the recording, presentation, and recognition of income standards that exist at Mountain Marry Hospital by following PSAK 23 regarding revenues at different rates to carry out internal controls over revenue and expenditure procedures cash adequately. The main principle of internal control that needs to be considered is the separation of tasks between recording, storage, cash receipts should be deposited to the bank, all-cash disbursements should use checks except for small amounts of expenses. Cash is all cash in hand and funds deposited in banks in various forms such as deposits and checking accounts. Data analysis methods used in this research is descriptive methods with qualitative analysis techniques that are outlining, describing and comparing data. The findings show that the service number of JKN patients at Mountain Marry Hospital has reached 90.05\% of JKN patients, so cash receipts at Mountain Marry Hospital have reached the government program to serve Jaminan Kesehatan Nasional (JKN) patients but based on research results the Mountain Marry Hospital has not recorded revenue recognition INACBG tariffs with JKN rates, by following the Statement of Financial Accounting Standards 23 because of differences in rates and are not sufficient to implement internal controls over cash receipts and disbursements procedures, especially for JKN patients.
\end{abstract}

\section{Pendahuluan}

Kesehatan pada dasarnya menjadi suatu prioritas bagi semua orang. Demi menjaga kesehatan setiap orang berusaha semampu mungkin dan semaksimal mungkin menjaga kesehatan karena kesehatan itu sangat penting setiap orang maka tidak sedikit orang berusaha untuk mempertahankan kesehatannya dengan mengikuti asuransi kesehatan yang ditawarkan oleh perusahaanperusahaan swasta maupun pemerintah dalam hal ini yang disebut adalah nonasuransi yaitu dengan Jaminan Kesehatan Nasional (JKN).

Rumah sakit sebagai suatu institusi pelayanan kesehatan menjalankan kegiatan dalam bentuk penjualan jasa dan keperluan medis yang membutuhkan pengelolaan keuangan secara baik dan benar. Pelaksanaan kegiatan operasional khususnya pada rumah sakit perlu memperhatikan perhitungan pendapatan yang diterima dari 
pasien yang datang berobat di rumah sakit. Kusumadewi dan Adam (2014) mengidentifikasikan beberapa masalah terkait siklus akuntansi sistem pendapatan, yaitu selisih klaim pasien karena perbedaan tarif BPSJ dan Rumah Sakit, pengakuan piutang, dan ketidaklengkapan dokumen Standar Operasional Prosedur, sedangkan penelitian Hastitoro (2019) mengidentifikasikan masalah piutang terkait otorisasi piutang pasien dan kelengkapan data pasien.

Rumah Sakit Gunung Maria Tomohon adalah rumah sakit seperti halnya rumah sakit umum lainnya yang memberikan pelayanan kesehatan bagi setiap pasien atau konsumennya, dalam hal ini Rumah Sakit Gunung Maria memiliki usaha penjualan obat-obatan serta alat kesehatan dan penjualan jasa lainnya. Pada sistem Penjualan Jasa yang dilakukan oleh Rumah Sakit Gunung Maria dalam pengelolaannya memberikan pelayanan paripurna kepada pasien atau konsumen yang datang berobat baik rawat jalan maupun rawat inap dengan melakukan transaksi penjualan jasa melalui pembayaran tunai ataupun pembayaran dengan menggunakan sistem piutang. Pendapatan kas dan piutang usaha menjadi jalan masuk pendapatan dari Rumah Sakit Gunung Maria.

Rumah Sakit Gunung Maria memiliki beberapa golongan piutang usaha seperti piutang kerjasama yaitu piutang yang muncul dari organisasi yang memiliki kerjasama dengan pihak rumah sakit dan juga piutang yang muncul dari konsumen/pasien umum yang datang berobat dan mendapat pelayanan jasa kesehatan begitu juga dengan piutang jasa asuransi yang tidak dibahas secara mendalam untuk asuransi rumah sakit. Dengan adanya piutang usaha tersebut perusahaan sangat rentan mengalami penghapusan piutang akibat piutang tak tertagih dari beberapa pelanggan. Karena piutang merupakan pintu masuk pendapatan yang sangat berpengaruh pada perusahaan maka perlu ada perhitungan pendapatan piutang yang dapat dihadapi dan mencegah masalah-masalah yang ada dalam pencatatan laporan keuangan.

Dalam PSAK No. 23 disebutkan: "Penjualan jasa menurut Standar Akuntansi Keuangan menyangkut pelaksanaan tugas entitas yang telah disepakati secara kontraktual untuk dilaksanakan selama suatu periode waktu. Pendapatan adalah arus masuk bruto dari manfaat ekonomik yang timbul dari aktivitas normal entitas selama periode jika arus masuk tersebut mengakibatkan kenaikan ekuitas yang tidak berasal dari kontribusi penanam modal". Namun demikian, manfaat yang diberikan oleh penulis tentang penerapan PSAK 23 tentang Pendapatan Jasa Pasien Jaminan Kesehatan Nasional (JKN) pada rumah sakit Gunung Maria dapat mengurangi kecurangan pada pencatatan pendapatan piutang.

Sistem pembayaran program Jaminan Kesehatan Nasional (JKN) berdasarkan tarif Indonesian-Case Based Groups (INA-CBG) atau sistem paket. rumah sakit akan mendapatkan pembayaran berdasarkan rata-rata biaya yang dihabiskan oleh suatu kelompok diagnosis. Sistem ini mempengaruhi pendapatan dan pengakuan piutang berdasarkan selisih tarif. Perlu adanya penerapan clinical pathway yang mengacu pada pembiayaan INA-CBG yang belum tentu diterapkan kepada semua penyakit hanya penyakit tertentu saja sehingga pendapatan yang diukur oleh rumah sakit berdasarkan billing system sesuai dengan pelayanan yang diberikan oleh dokter kepada pasien berdasarkan tarif rumah sakit bukan tarif INA-CBG yang seharusnya perlakuan pendapatan untuk pasien umum maupun pasien BPJS berbeda, namun pada praktiknya rumah sakit menerapkan tarif yang sama pada pasien meskipun terdapat perbedaan pembayaran yang diterima.

\section{Tinjauan pustaka}

Akuntansi. Akuntansi adalah suatu seni pencatatan, penggolongan, dan peringkasan transaksi dan kejadian ekonomi perusahaan yang dapat diukur dengan satuan moneter dan hasilnya diinterpretasikan (Tanor, 2015). Tujuan akuntansi adalah menyajikan 
informasi keuangan perusahaan yang berguna dalam pengambilan keputusan (Tinungki, 2014).

Akuntansi keuangan. Akuntansi keuangan (financial accounting) adalah sebuah proses yang hasil akhirnya adalah laporan keuangan yang disusun berdasarkan bukti transaksi perusahaan secara keseluruhan dan digunakan baik oleh pihak-pihak internal maupun pihak eksternal (Kieso, et al. 2011:5). Tujuan Pelaporan Keuangan bertujuan umum adalah untuk menyediakan informasi keuangan suatu entitas yang berguna bagi pengambilan keputusan oleh investor saat ini dan investor pontensial, pemberi pinjaman, dan kreditor lainnya dalam membuat keputusan tentang penyediaan sumber daya kepada entitas.

Pengukuran dan pengakuan pendapatan. Pengukuran pendapatan dalam PSAK No 23 Standar Akuntansi Keuangan menyatakan bahwa pendapatan diukur dengan nilai wajar imbalan yang diterima atau yang dapat diterima. Jumlah Pendapatan timbul dari transaksi hasil persetujuan antara entitas dengan pembeli atau pengguna asset tersebut. Jumlah pendapatan tersebut diukur pada nilai wajar imbalan yang diterima atau dapat diterima dikurangi jumlah diskon usaha dan rabat volume yang diperbolehkan oleh entitas. Jika barang atau jasa dipertukarkan untuk barang dan jasa dengan sifat dan nilai serupa, maka pertukaran tersebut tidak dianggap sebagai transaksi yang menghasilkan pendapatan.

Laporan keuangan. Laporan keuangan merupakan suatu informasi keuangan yang memberikan gambaran kondisi dan kinerja suatu perusahaan (Fahmi 2011: 22). Laporan keuangan yang lengkap terdiri: Neraca, Laporan Laba Rugi Komprehensif, Laporan Perubahan Ekuitas, Laporan Perubahan Posisi Keuangan yang disajikan berupa Laporan Arus Kas atau Laporan Arus Dana, Catatan dan Laporan Lain serta materi penjelasan yang merupakan bagian integral dari laporan keuangan. Unsur yang berkaitan secara langsung dengan pengukuran posisi keuangan adalah aset, kewajiban, dan ekuitas. Sedangkan unsur pengukuran kinerja dalam laporan laba rugi adalah penghasilan dan beban. Laporan posisi keuangan mencerminkan berbagai unsur laporan laba rugi dan perubahan dalam berbagai unsur neraca. Laporan keuangan disusun untuk memenuhi kebutuhan pengguna laporan keuangan. Laporan keuangan merupakan hasil akhir dari proses pencatatan dan pengikhtisaran data transaksi ekonomi perusahaan. Seorang akuntan diharapkan mampu untuk mengorganisir seluruh data akuntansi hingga menghasilkan laporan keuangan, dan selanjutnya menginterpretasikan serta menganalisis laporan keuangan tersebut (Hery 2015: 3). Tujuan laporan keuangan menurut Pernyataan Standar Akuntansi Keuangan (PSAK) No.1 (Revisi 2009) adalah memberikan informasi mengenai posisi keuangan, kinerja keuangan dan arus kas entitas yang bermanfaat bagi pengguna laporan dalam pengambilan keputusan ekonomi. Tujuan laporan keuangan secara umum yakni memberikan informasi keuangan: (1) mengenai sumber-sumber ekonomi dan kewajiban serta modal suatu perusahaan; (2) perubahan sumber-sumber ekonomi netto (sumber dikurangi kewajiban) suatu perusahaan yang timbul dari aktivitas-aktivitas usaha dalam rangka memperoleh laba; (3) mengestimasi potensi perusahaan dalam menghasilkan laba; (4) mengenai perubahan dalam sumber-sumber ekonomi dan kewajiban; dan (5) berhubungan dengan laporan keuangan yang relevan untuk kebutuhan pemakai laporan. Menurut (Standar Akuntansi Keuangan/SAK: 2009) adalah suatu kerangka dalam prosedur pembuatan laporan keuangan yang bertujuan untuk menyeragamkan penyajian laporan keuangan. Standar Akuntansi Keuangan (SAK) tahun 2009 yang memuat aturanaturan yang digunakan dalam pengukuran dan penyajian laporan keuangan. Informasi dalam laporan keuangan yang berkualitas harus mencakup beberapa unsur pokok yaitu:

1. Dapat dipahami: kualitas penting informasi yang ditampung dalam laporan keuangan adalah kemudahannya 
untuk segera dapat dipahami oleh pengguna laporan keuangan.

2. Relevan: informasi harus dapat mempengaruhi keputusan ekonomi pemakai dengan membantu mengevaluasi peristiwa masa lalu, masa kini, atau masa depan, menegaskan atau mengoreksi hasil evaluasi di masa lalu.

3. Keandalan: informasi harus bebas dari pengertian yang menyesatkan, kesalahan material dan dapat diandalkan pemakainya sebagai penyajian yang tulus atau jujur dari seharusnya disajikan, atau yang secara wajar diharapkan dapat disajikan.

4. Dapat diperbandingkan: laporan keuangan harus dapat diperbandingkan antar periode untuk mengidentifikasi kecenderungan posisi dan kinerja perusahaan, serta mengevaluasi posisi keuangan, kinerja serta perubahan posisi keuangan secara relatif.

Menurut (Standar Akuntansi Keuangan/SAK: 2009) pada bagian kerangka dasar penyusunan dan penyajian laporan keuangan, unsur-unsur laporan keuangan termasuk di dalamnya yaitu: Posisi Keuangan merupakan unsur-unsur yang berkaitan langsung dengan pengukuran posisi keuangan adalah asset, liabilitas, dan ekuitas yang didefinisikan:

a. Aset, yaitu sumber daya yang dikuasai oleh perusahaan sebagai akibat dariperistiwa masa lalu dan dari mana manfaat ekonomi dimasa depan diharapkan diperoleh perusahaan.

b. Liabilitas, yaitu hutang perusahaan masa kini yang timbul dari peristiwa masa lalu, yang penyelesaiannya diharapkan mengakibatkan arus keluar dari sumber daya perusahaan yang mengandung manfaat ekonomi.

c. Ekuitas, yaitu hak residual atas aset perusahaan setelah dikurangi semua kewajiban.

Penghasilan bersih (laba) sering kali digunakan sebagai ukuran kinerja. Unsur yang langsung berkaitan dengan pengukuran laba adalah penghasilan dan beban. Penghasilan (income) adalah kenaikkan manfaat ekonomik selama suatu periode akuntansi dalam bentuk pemasukan atau peningkatan asset atau penurunan liabilitas yang mengakibatkan kenaikan pada ekuitas yang tidak berasal dari kontribusi penanam modal. Jenis-jenis laporan keuangan menurut Pernyataan Standar Akuntansi Keuangan (PSAK) menurut Standar Akuntansi Keuangan/SAK 2009 adalah:

1. Laporan laba rugi (Income Statement). Merupakan ikhtisar pengaruh-pengaruh finansial dari usahausaha perusahaan yang menguntungkan atau merugikan selama periode tertentu.

2. Laporan Arus Kas. Menunjukkan aliran masuk dan keluar uang tunai (kas) perusahaan pada suatu periode akuntansi.

3. Laporan Posisi Keuangan. Laporan posisi keuangan adalah sebuah laporan yang sistematis tentang posisi aset, kewajiban dan ekuitas perusahaan per tanggal tertentu, yang menggambarkan posisi keuangan perusahaan.

4. Laporan Perubahan Modal. Laporan ini mengidentifikasikan kenaikan atau penurunan modal kerja serta besarnya perubahan modal kerja, antara dua titik waktu.

5. Catatan Atas Laporan Keuangan. Menjelaskan secara detail item-item yang disajikan dalam laporan keuangan tentang hasil usaha dan posisi keuangan perusahaan.

Tujuan dan fungsi laporan keuangan. Terdapat perbedaan tujuan dan fungsi pada organisasi publik dan organisasi swasta yang menyebabkan perbedaan laporan keuangan pada kedua organisasi ini (Mardiasmo, 2009:161-162). Laporan keuangan bertujuan untuk menyampaikan informasi keuangan perusahaan pada suatu periode tertentu kepada para pemangku kepentingan. Informasi ini kemudian digunakan sebagai acuan dalam pengambilan keputusan menyangkut penggunaan sumber daya. Menurut Samryn (2012:33) perkembangan kebutuhan pengguna laporan keuangan mendorong timbulnya tujuan yang diperluas, yaitu: (1) membuat keputusan investasi dan kredit; (2) menilai prospek arus kas; (3) melaporkan sumber daya 
perusahaan, klaim atas sumber daya tersebut, dan perubahan-perubahan di dalamnya; (4) sumber daya ekonomi, kewajiban, dan ekuitas para pemilik; (5) melaporkan kinerja dan laba perusahaan; (6) menilai likuiditas, solvabilitas dan arus dana; (7) pengelolaan dan kinerja manajemen; dan (8) menilai pengelolaan dan kinerja manajemen. Berdasarkan Kerangka Dasar Penyusunan dan Penyajian Laporan Keuangan maka tujuan laporan keuangan adalah menyediakan informasi tentang posisi keuangan, kinerja serta perubahan posisi keuangan suatu perusahaan yang bermanfaat sebagai dasar pengambilan keputusan oleh pengguna laporan keuangan (Kartikahadi, et al., 2012:46). Imbalan yang diterima atas jasa yang diberikan dalam laporan keuangan merupakan pengakuan pendapatan untuk imbalan jasa keuangan bergantung pada tujuan imbalan tersebut dinilai. Imbalan untuk jasa keuangan mungkin tidak mengindikasikan sifat dan substansi jasa yang diberikan seperti penghasilan yang diakui berdasarkan kenaikan manfaat ekonomik masa depan akibat kenaikan asset atau penurunan liabilitas telah terjadi dan dapat diukur dengan andal.

Pengertian dan unsur-unsur laporan keuangan. Didalam unsur-unsur laporan keuangan menurut (Islahuzzaman,2012) dan dalam kamus standar akuntansi menurut (Ardyos, 2014) ada beberapa istilah dan pengertian umum dari unsur-unsur yang ada di dalam laporan adalah sebagai berikut:

1. Klasifikasi Aktiva yaitu proses pengelompokkan sumber-sumber daya ekonomi dalam kategori yang pas. Kelompok aktiva terdiri dari aktiva lancar (current assets), aktiva tetap (fixed assets), aktiva tak berwujud (intangible assets), investasi, dan biaya-biaya yang ditangguhkan (deferred costs). Aktiva dikelompokkan ke dalam kelompokkelompok utama, untuk memudahkan analisa kesehatan keuangan suatu badan usaha.

2. Aktiva (Assets) adalah manfaat ekonomi yang mungkin terjadi di masa depan, yang diperoleh atau dikendalikan oleh entitas sebagai hasil dari transaksi atau peristiwa di masa lalu. Aktiva juga didefenisikan sebagai hak-hak dan kekayaan/harta-harta yang merupakan sumber penghasilan, sumber-sumber ekonomi yang diharapkan dapat memberikan hasil menguntungkan atas kegiatan-kegiatan pada masa sekarang dan pada masa yang datang, atau hartaharta yang dimiliki pada saat ini.

1. Aktiva berwujud (tangible assets) adalah aktiva secara fisik dapat dilihat. Contohnya Bangunan, Kendaraan bermotor, Tanah dan lain-lain.

2. Aktiva Lancar (current assets) adalah kas dan aktiva lainnya yang diharapkan dapat dikonversi menjadi kas, dijual, atau dikonsumsi dalam waktu satu tahun atau dalam satu siklus operasi normal perusahaan, tergantung mana yang paling lama. Pengertian lain aktiva lancar adalah uang kas atau aktiva lainnya yang dapat diharapkan untuk dicairkan atau ditukarkan menjadi uang tunai, dijual atau dipakai pada periode berikutnya (paling lama dalam waktu satu tahun atau dalam perputaran kegiatan perusahaan). Kas merupakan aktiva yang paling likuid (lancar), lalu diikuti dengan investasi jangka pendek, piutang, persediaan, dan biaya dibayar dimuka.

3. Aktiva Tidak Lancar (Non current assets) adalah aktiva yang tidak memenuhi definisi aktiva lancar. Aktiva tidak lancar mencakup berbagai pos, yaitu investasi jangka panjang (yang sering disebut investasi saja), aktiva tetap, aktiva tidak berwujud, dan aktiva tidak lancar lainnya. Pengertian lain aktiva tidak lancar adalah aktiva yang mempunyai umur ekonomis lebih dari satu tahun atau tidak habis dalam satu kali perputaran operasi perusahaan.

4. Kewajiban (liability) adalah kewajiban ekonomi dari suatu perusahaan. Yaitu jumlah terutang kepada kreditor, pekerja, pemerintah atau 
yang lainnya. Selain itu kewajiban adalah semua kewajiban keuangan perusahaan kepada pihak lain yang belum terpenuhi, dimana utang ini merupakan sumber dana atau modal perusahaan yang berasal dari kreditor. Kewajiban juga adalah pengorbanan atas manfaat ekonomi yang mungkin terjadi di masa depan, yang timbul dari kewajiban entitas pada saat ini, untuk menyerahkan aktiva atau memberikan jasa kepada entitas lainnya di masa depan sebagai hasil dari transaksi atau peristiwa di masa lalu.

5. Kewajiban Lancar (current liabilities) atau utang lancar. Kewajiban keuangan (liabilities) yang jatuh tempo dalam waktu setahun. kewajiban yang diperkirakan akan dibayar dengan menggunakan aktiva lancar atau menciptakan kewajiban lainnya dan harus segera dilunasi dalam jangka waktu satu tahun atau dalam satu siklus operasi normal perusahaan, tergantung mana yang paling lama.

6. Kewajiban Tidak Lancar adalah kewajiban yang diperkirakan tidak dibayar dalam waktu 12 bulan atau dalam satu siklus operasi normal perusahaan.

7. Ekuitas adalah kepemilikan atau kepentingan residu dalam aktiva entitas, yang masih tersisa setelah dikurangi dengan kewajibannya.

8. Investasi oleh pemilikadalah kenaikan ekuitas (aktiva bersih) entitas yang dihasilkan dari penyerahan sesuatu yang bernilai oleh entitas lain untuk memperoleh atau meningkatkan bagian kepemilikannya.

9. Pendapatan (Income) adalah arus masuk aktiva atau peningkatan lainnya atas aktiva atau penyelesaian kewajiban entitas (atau kombinasi dari keduanya) dari pengiriman barang pemberian jasa, atau aktivitas lainnya yang merupakan operasi utama atau operasi sentral perusahaan.

10. Beban (Expenses) adalah arus keluar aktiva atau penggunaan lainnya atas aktiva atau terjadinya (munculnya) kewajiban entitas (atau kombinasi dari keduanya) yang disebabkan oleh pengiriman atau pembuatan barang, pemberian jasa, atau aktivitas lainnya yang merupakan operasi utama atau operasi sentral perusahaan. Selain itu beban adalah pengorbanan ekonomis yang diperlukan untuk memperoleh barang dan jasa.

11. Kas (cash) adalah uang tunai, check dan rekening bank. Kas merupakan suatu aktiva lancar meliputi uang logam, uang kertas, dan pos-pos lain yang dapat digunakan sebagai alat tukar dan mempunyai dasar pengukuran akuntansi.

12. Kas di Bank (cash in the Bank) Uang yang disimpan di bank dan barang yang disetujui bank untuk disimpan dengan segera (mis, uang kertas, koin, cek, wesel)

\section{Metode penelitian}

Penelitian ini menggunakan metode deskriptif-kuantitatif, yaitu suatu metode yang menggunakan data berupa fakta-fakta dari objek penelitian yang diperoleh dari objek penelitian, guna mendapatkan gambaran yang benar tentang objek yang diteliti (Sugiyono, 2012 : 29). Penelitian ini menggunakan data primer yang diperoleh secara langsung dari objek penelitian melalui wawancara langsung dengan pegawai dan juga pimpinan dari objek penelitian, yaitu Rumah Sakit Gunung Maria. Penelitian ini menggunakan analisis deskriptif yaitu mendeskripsikan objek yang diteliti berdasarkan data yang diperoleh dan membuat kesimpulan secara umum.

\section{Hasil penelitian dan pembahasan Hasil penelitian \\ Dalam membuat laporan persandingan tarif INACBG-s dengan tarif Rumah Sakit}


Gunung Maria Tomohon maka akan dijelaskan sebagai berikut: Pada laporan keuangan Rumah Sakit Gunung Maria Tomohon yang ada tidak mencatat pendapatan selisih pembayaran kurang atau lebih dari klaim INACBG-s dengan tarif Rumah Sakit hanya mencatat pendapatan per kelas perawatan pasien berdasarkan Billing Pasien tidak ada pemisahan pendapatan umum maupun pendapatan klaim pasien JKN. Tabel 1 adalah data rekapan persandingan klaim tarif rumah sakit dengan tarif INACBG-s yang diajukan rumah sakit ke BPJS.

Tabel 1 Daftar rekapan persandingan piutang pasien Jaminan Kesehatan National tahun 2017

\begin{tabular}{|c|c|c|c|}
\hline Bulan & Total Tarif Rumah Sakit & Total Tarif Klaim JKN & Selisih Persandingan Tahun 2017 \\
\hline Triwulan I & Rp10.770.525.300,00 & Rp10.339.728.961,00 & $\operatorname{Rp}(430.796 .339,00)$ \\
\hline Triwulan II & Rp12.624.951.234,00 & Rp12.093.476.100,00 & $\mathrm{Rp}(531.475 .134,00)$ \\
\hline Triwulan III & Rp12.129.061.540,00 & Rp11.704.867.400,00 & $\mathrm{Rp}(424.194 .140,00)$ \\
\hline Triwulan IV & Rp11.493.676.301,00 & Rp11.401.260.900,00 & $\operatorname{Rp}(92.415 .401,00)$ \\
\hline Total & Rp47.018.214.375,00 & Rp45.539.333.361,00 & $\operatorname{Rp}(1.478 .881 .014,00)$ \\
\hline
\end{tabular}

Berdasarkan Tabel 1 diatas dapat dilihat selisih biaya tarif rumah sakit pada tahun 2017 dengan total tarif Rumah Sakit adalah sebesar Rp. 47.018.214.375, 00. Yang diajukan ke kantor BPJS berdasarkan Billing Per Pasien yang sudah di entri ke kementerian kesehatan setelah di verifikasi data klaim menjadi total tarif klaim JKN pada tahun 2017 adalah sebesar Rp. 45.539.333.361,00.Sehingga pengakuan Jumlah pendapatan tarif Jaminan Kesehatan Nasional (JKN) yang diterima sampai pada tahun 2017 adalah sebesar Rp. 45.539.333.361,00 yang telah dijurnalkan pada laporan keseluruhan pendapatan JKN. Sedangkan persandingan selisih tarif antara rumah sakit dengan tarif JKN tahun 2017 adalah sebesar Rp. $(1.478 .881 .014,00)$ yang dicatat sebagai diskon rumah sakit terhadap Jaminan Kesehatan Nasional.

\section{Pembahasan}

Perhitungan pendapatan pada pencatatan dalam laporan keuangan tentunya memiliki perbedaan tarif rumah sakit dengan tarif Jaminan Kesehatan Nasional (JKN). Hal ini memerlukan penyesuaian tarif yang dibuat dalam jurnal pencatatan di rumah sakit Gunung Maria Tomohon yaitu pencatatan pada jurnal pendapatan pasien umum dan jurnal pada pasien JKN. Tabel 2 menyajikan salah satu sampel dari pasien JKN yang dirawat di Rumah Sakit Gunung Maria dengan tindakan Phacoemulsification pada pasien mata. Berdasarkan Tabel 2, catatan atas laporan keuangan menunjukkan selisih lebih atau kurang dalam pengakuan pendapatan yang diterima Rumah Sakit Gunung Maria Tomohon dalam pengajuan klaim pembayaran JKN dengan menggunakan sistem paket per diagnose atau per penyakit yang dialami oleh pasien sedangkan tarif Rumah Sakit Gunung Maria Tomohon membayarkan berdasarkan rincian tindakan dan penggunaan alat kesehatan (alkes) maupun fasilitas lainnya yang disediakan oleh Rumah Sakit sehingga berpengaruh pada system pengakuan pendapatan pada saat belum pembayaran dan setelah pembayaran klaim karena berdasarkan verifikasi dari bagian JKN sendiri. 
Tabel 2. Perbedaan tarif Jaminan Kesehatan Nasional (JKN) dengan tarif Rumah Sakit Gunung Maria Tomohon dan pencatatan akuntansinya

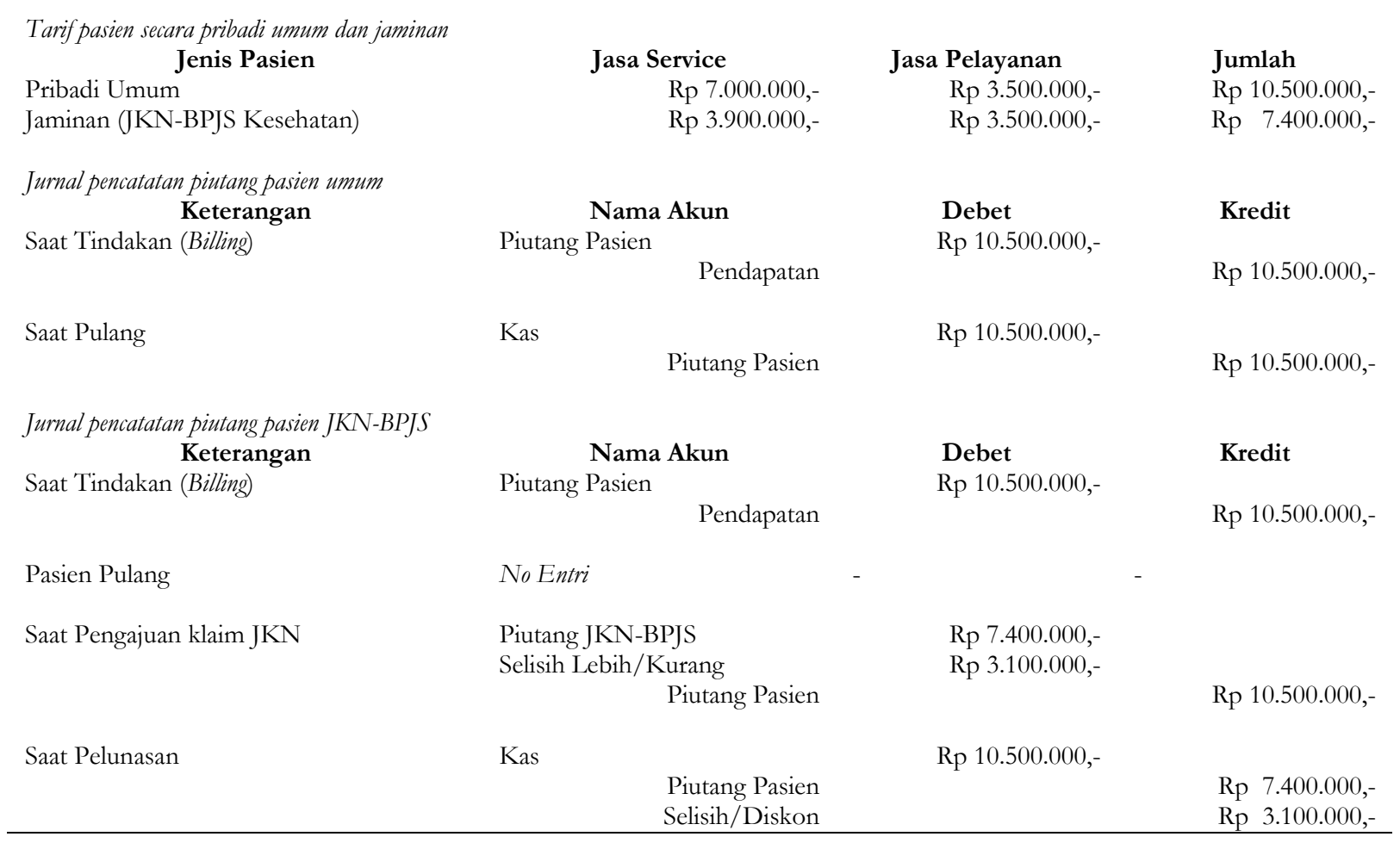

\section{Kesimpulan dan saran} Kesimpulan

Berdasarkan pembahasan maka ditarik kesimpulan sebagai berikut:

1.Rumah Sakit Gunung Maria Tomohon dengan Tim Pengendali Mutu dan Pengendali Biaya dapat merubah tarif Rumah Sakit Berdasarkan Tarif INACBG-s yang disesuaikan dengan Clinical Pathway Rumah Sakit.

2.Penerapan Laporan Keuangan Rumah Sakit Gunung Maria yang ada perlu dibuatkan jurnal atau menambah akun cadangan kerugian piutang JKN pada laporan keuangan yang sesua idengan standar sehingga dapat memberikan pencatatan laporan keuangan yang baik dan akurat bila dapat diterapkan dengan baik tidak langsung dibuatkan pada pencatatan diskon yang catat pada semua transaksi.

3.Dengan cara membuat siklus akuntansi yang sesuai dengan standar akuntansi keuangan mulai dengan pencatatan jurnal pada kas harian lalu diposting ke buku besar sampai pada laporan keuangan dan untuk yang mengikuti standar PSAK No. 23 bagi rumah sakit Gunung Maria masih perlu ada perhitungan cost yang riil dengan bagian-bagian terkait dalam pembuatan tarif rumah sakit ke depannya dan disesuaikan dengan tarif INACBG-s pada pembagian unit cost dalam billing pasien JKN.

\section{Saran}

Berdasarkan kesimpulan yang di atas, saran penelitian ini adalah:

1. Rumah Sakit Gunung Maria perlu memperbaharui tarif pada billing pasien berdasarkan tarif INACBG-s yang disesuaikan dengan Clinical Pathway dan pengakuan pendapatan jasa pada PSAK No. 23 dicatat pada pos pendapatan riil dan piutang rill yang akan ditagihkan ke Badan Penyelenggara Jaminan Sosial

2. Jurnal Cadangan Kerugian Piutang Jaminan Kesehatan Nasional pada Piutang Jaminan Kesehatan Nasional harusnya di catat langsung pada persandingan piutang tiap bulan yang dibayarkan ke Rumah Sakit berdasarkan hasil verifikasi klaim Jaminan Kesehatan Nasional.

3. Ada baiknya apabila dapat mengikuti siklus akuntansi yang sesuai dengan standard akuntansi pada umumnya sehingga dapat menghasilkan Laporan Keuangan dan disesuaikan dengan 
standar PSAK No. 23 tentang Pengakuan Pendapatan.

\section{Daftar pustaka}

Ardiyos. (2014). Kamus Besar Akuntansi. Jakarta: Citra Harta Prima.

Fahmi, I. (2011). Analisis Laporan Akuntansi. Bandung: Alfabeta.

Ikatan Akuntansi Indonesia. (2009). Standar Akuntansi Keuangan, Jakarta: Dewan Standar Akuntansi Keuangan.

Hastitoro, D.. (2019). Analisis sistem pengendalian internal pada siklus pendapatan dan pengeluaran kas (Studi kasus pada Rumah Sakit Wava Husada Kabupaten Malang). Jurnal Ilmiah Mahasiswa FEB 7(2), $\quad$ 1-20. https://jimfeb.ub.ac.id/index.php/jimfeb/article /view/5715

Kartikahadi, H., Sinaga, R., U., Syamsul., M., \& Siregar, S., V. (2012), Kerangka Dasar Penyusunan dan Penyajian Laporan Keuangan, Jakarta.

Kieso, D. E., Weygandt, J. J., \& Warfield, T. D. (2011). Intermediate Accounting Volume 1 IFRS Edition. United States of America : Wiley.

Kusumadewi, A., W. \& Adam, H. (2014). Analisis sistem informasi akuntansi siklus pendapatan (Studi kasus pada RSUD dr. "X"). Jurnal Ilmiah Mahasiswa $\quad$ FEB, $\quad 3(1), \quad$ 1-19. https://jimfeb.ub.ac.id/index.php/jimfeb/article /view/1572

Mardiasmo. (2009). Akuntansi sektor publik. Yogyakarta: Andi Yogyakarta

Islahuzzaman .(2012). Istilah-Istilah akuntansi dan auditing, Jakarta: Bumiaksara.

Sugiyono. (2012). Metode penelitian bisnis (cetakan 16) Bandung: Alfabeta.

Sunyoto, D. (2013). Metodologi penelitian akuntansi. Bandung: Refika Aditama.

Tanor, M., O., Sabijono, H., \& Walandouw, S., K. (2015). Analisis laporan keuangan dalam mengukur kinerja keuangan pada PT. Bank Artha Graha Internasional,

Tbk. https://doi.org/10.35794/emba.v3i3.9535

Samryn, L., M. (2014). Pengantar akuntansi. Edisi IFRS. Jakarta: Rajawali Pers.

Samryn, L., M. (2012). Pengantar akuntansi mudah membut jurnal dengan pendekatan siklus transaksi. Jakarta: PT. Raja Grafindo Persada

Tinungki, A., N., M., \& Pusung, R., J. (2014). Penerapan laporan keuangan organisasi nirlaba berdasarkan PSAK No.45 pada Panti Sosial Tresna Werdha Hana. Jurnal EMBA: Jurnal Riset Ekonomi, Manajemen dan Akuntansi, 2(2), 809-819. https://doi.org/10.35794/emba.v2i2.4417

Hery. (2015). Mahir Accounting Principles. Jakarta: Penerbit PT Grasindo anggota IKAPI.

Ikatan Akuntansi Indonesia 2009, Standar Akuntansi Keuangan, Jakarta: Dewan Standar Akuntansi Keuangan.

Undang-Undang

Rumah

Sakit http://www.depkes.go.id/resource/download/ peraturan/UU No. 44 Th 2009 ttg Rumah Sakit. perdhaki.org
Undang-Undang Republik Indonesia Nomor 36 Tahun 2009 Tentang Kesehatan. http://perdhaki.org/sites/default/files/UU\%20 KESEHATAN\%2036-2018.pdf

rsgunungmaria.com (5 Maret 20019). Visi dan Misi. Diunduh tanggal 5 Maret 2019. (http://rsgunungmaria.com/tentang-kami/). 